\title{
Postdocs face hardship across mainland Europe
}

\section{Those who follow the funding and work abroad may not find a job when they go home.}

Sir-As a French postdoc currently living in England, I would like to comment on your News Feature on this topic, "Young, gifted... and spurned" (Nature 414, 145; 2001), and the two Correspondences arising from it (P.-L. Chau Nature 414, 582; 2001 and M. Bailly, Nature 415, 13; 2002).

Comparing France with the United Kingdom in the way that Chau does is inappropriate; and contrary to the impression that may have been given by your News Feature, the situation of French postdocs is (unfortunately) all too common across mainland Europe.

First, Chau's statement “There are more postdocs for each tenured post in the British system than in the French system" cannot be taken, as he intends, to mean that competition is fiercer in Britain, because it ignores the fact that many postdocs currently living there are from other European countries and wish eventually to find a job in their home country.

I agree that it is easier for a French postdoc to find a permanent position in the United Kingdom than for a UK or other foreign postdoc to find one in France (see the Correspondence by A. Munk Nature 413, 772; 2001), but this applies mainly to teaching positions.

Because English is the standard scientific language, it seems unfair to compare France to the United Kingdom by using the ratio of postdocs to tenured staff in the two countries. There are more opportunities for funding postdoctoral positions in the United Kingdom than in France. Even the European TMR (training and mobility of researchers) grants, designed to favour movement of scientists across Europe, are mostly allocated to positions in the United Kingdom: approximately twice as many as for France and 10 times the number for Greece.

Nevertheless, the French system is improving as positions become available to non-French scientists, and I would not call French postdocs "spurned".

Second, my Spanish, Portuguese and Italian postdoc friends all feel the same as I do. Many PhD students face the choice of either leaving their home country to acquire new scientific experiences but risk being forgotten, or staying at home to build scientific relationships. The price for the latter choice, as Bailly aptly puts it, is to "spend ... time begging for short-term funding which ... barely supports a decent living".

Most postdocs I know (mostly from
Spain, Portugal or Italy) feel that they made the right scientific choice by working abroad. But they also feel that jobs are given too often to those who stayed, as discussed in your News Feature.

The case of Claire Amadou described in this feature is unfortunately all too common. But she could equally have been called Clara Rodriguez, Vieira or Romanelli.
It is surely time to analyse the situation at the European level (see Nature 413, 768-770; 2001). What are the odds in favour of young scientists in different European states building a scientific career in their home countries?

\section{Lounès Chikhi}

Department of Biology, Darwin Building, University College London,

London WC1E 6BT, UK

\section{PhD students also need to make their voices heard}

Sir-Nature pays a lot of attention to the plight of postdocs everywhere (see for example Nature 407, 119 and 408, 637; 2000; and 410, 137; 2001) and North American PhD students (see Nature 409, 442; 2001) but only occasionally to European PhD students (see Nature 410, 299; 2001). European science needs a sense of European identity before it can speak with one voice.

For this reason, students and young scientists from 15 countries have collaborated to found Eurodoc, the Council for European doctoral and postdoctoral students (www.precarios.org/eurodoc/ index.htm). It includes the national PhD, or $\mathrm{PhD}$ and postdoctoral, students' unions of Finland, France, Germany, Italy, Hungary, the Netherlands, Spain, Sweden and the United Kingdom; and local unions from Belgium (Leuven), Estonia (Tartu), Greece (Athens), Ireland, Latvia and Slovakia. Eurodoc's second general assembly will be in Girona, Spain, from 31 January to 3 February 2002.

The organization is not only revealing similarities in the difficulties that students face throughout Europe, but is also highlighting the differences between education systems. One of Eurodoc's functions is to identify these disparities and bring them to the attention of the European Union, European governments' education ministries, scientific societies and the public.

Senior scientists and politicians are already aware of some problems faced by $\mathrm{PhD}$ students, but others are unknown or their importance is not properly understood. Eurodoc will therefore explain national systems and report problems, from the student perspective, to the scientific community to encourage international discussion about these European issues.

\section{T. L. Raoul Tan}

Former president, Eurodoc, and Department of Cell Biology and Genetics, Erasmus University, PO Box 1738, 3000 DR Rotterdam, Holland

\section{Cultural heritage shared}

Sir - Your News report about the law covering repatriation of Native American items in California(Nature 414, 139; 2001) was even-handed and correct - it can be difficult to follow the NAGPRA statute.

As a retired director of the Harvard Peabody Museum, I know the Tlingit totem pole shown in your photograph and it has been returned to the Tlingits. It was a gift from a Mr Harriman, who obtained it from a professional 'collector' who took four such poles in around 1900 from a Tlingit village that was presumed to be deserted. We now know the Tlingits had moved away only temporarily, to protect themselves from a smallpox epidemic.

We have had very good interactions with that tribe. In the mid-1970s (while I was director), Rosita Worl, a Tlingit student in our department of anthropology, helped me put together a major exhibition using the museum's great early (1860s) collection of Tlingit artefacts. Through Ms Worl, I was able to get help from people in Alaska to curate the exhibition; I brought Nathan Jackson, a Tlingit, to the museum for about five months to make a large wall carving. He, Ms Worl and about 10 more Tlingits did a series of public dance performances.

When the museum received the request for the repatriation of the pole, the current director, Rubie Watson, asked Nathan to make a new pole for the museum. On 19 November, Jackson and his family, Dr Worl (who got her PhD in anthropology from Harvard recently) and other Tlingits danced again in the museum under the shadow of the new pole. Stephen Williams PO Box 22354, Santa Fe, New Mexico 87502, USA 